\title{
Effects of Heavy, Tracked-Vehicle Disturbance on Forest Soil Properties at Fort Benning, Georgia
}

May 2004

C.T. Garten, Jr., and T.L. Ashwood

Environmental Sciences Division

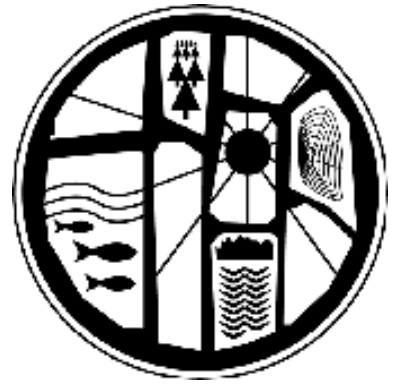




\section{DOCUMENT AVAILABILITY}

Reports produced after January 1, 1996, are generally available free via the U.S. Department of Energy (DOE) Information Bridge.

Web site http://www.osti.gov/bridge

Reports produced before January 1, 1996, may be purchased by members of the public from the following source.

National Technical Information Service

5285 Port Royal Road

Springfield, VA 22161

Telephone 703-605-6000 (1-800-553-6847)

TDD 703-487-4639

Fax 703-605-6900

E-mail info@ntis.fedworld.gov

Web site http://www.ntis.gov/support/ordernowabout.htm

Reports are available to DOE employees, DOE contractors, Energy Technology Data Exchange (ETDE) representatives, and International Nuclear Information System (INIS) representatives from the following source.

Office of Scientific and Technical Information

P.O. Box 62

Oak Ridge, TN 37831

Telephone 865-576-8401

Fax 865-576-5728

E-mail reports@adonis.osti.gov

Web site http://www.osti.gov/contact.html

This report was prepared as an account of work sponsored by an agency of the United States Government. Neither the United States Government nor any agency thereof, nor any of their employees, makes any warranty, express or implied, or assumes any legal liability or responsibility for the accuracy, completeness, or usefulness of any information, apparatus, product, or process disclosed, or represents that its use would not infringe privately owned rights. Reference herein to any specific commercial product, process, or service by trade name, trademark, manufacturer, or otherwise, does not necessarily constitute or imply its endorsement, recommendation, or favoring by the United States Government or any agency thereof. The views and opinions of authors expressed herein do not necessarily state or reflect those of the United States Government or any agency thereof. 
Environmental Sciences Division

\title{
EFFECTS OF HEAVY, TRACKED-VEHICLE DISTURBANCE ON FOREST SOIL PROPERTIES AT FORT BENNING, GEORGIA
}

\author{
C.T. Garten, Jr., and T.L. Ashwood ${ }^{1}$ \\ Environmental Sciences Division \\ Oak Ridge National Laboratory
}

Date Published: May 2004

\author{
Prepared for \\ Strategic Environmental Research and Development Program (SERDP) \\ Ecosystem Management Program (SEMP) \\ Budget Activity Number 4015 ER 010 \\ Prepared by \\ OAK RIDGE NATIONAL LABORATORY \\ Oak Ridge, Tennessee 37831 \\ managed by \\ UT-BATTELLE, LLC \\ for the \\ U.S. DEPARTMENT OF ENERGY \\ under contract DE-AC05-00OR22725
}

\footnotetext{
${ }^{1}$ Retired
} 



\section{CONTENTS}

LIST OF TABLES...........................................................................

ACKNOWLEDGMENTS...................................................................... vii

ABSTRACT

1. INTRODUCTION...............................................................................

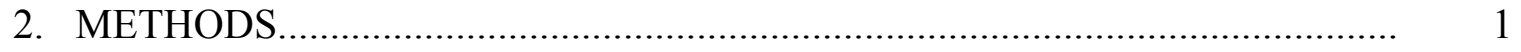

2.1 STUDY SITE .................................................................................

2.2 SOIL SAMPLING ......................................................................... 2

2.3 SAMPLE ANALYSIS...................................................................... 2

2.3.1 Soil Carbon and Nitrogen............................................................. 2

2.3.2 Physical Fractionation of Soils....................................................... 2

2.3.3 Soil Nitrogen Availability ......................................................... 3

2.3.4 Elemental Analysis...................................................................... 3

2.3.5 Calculations...................................................................... 3

2.3.6 Statistical Analysis.................................................................. 4

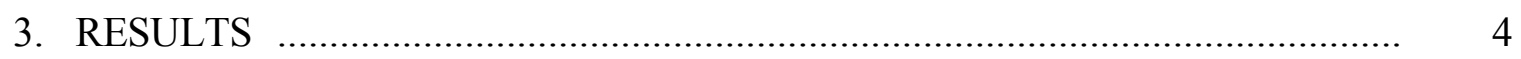

3.1 PRE-DISTURBANCE SOIL SAMPLING............................................. 4

3.1.1 O-Horizon.............................................................................. 4

3.1.2 Whole Mineral Soil.......................................................................... 5

3.1.3 Physical Fractionation of Soils................................................... 5

3.1.4 Soil Nitrogen Availability................................................................... 6

3.2 POST-DISTURBANCE SOIL SAMPLING .......................................... 8

3.2.1 O-Horizon................................................................................... 8

3.2.2 Whole Mineral Soil.......................................................................... 9

3.2.3 Physical Fractionation of Soil..................................................... 9

3.2.4 Soil Nitrogen Availability.......................................................... 10

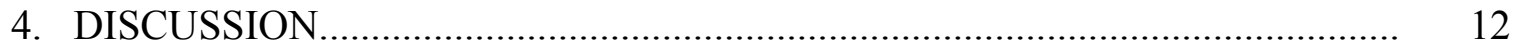

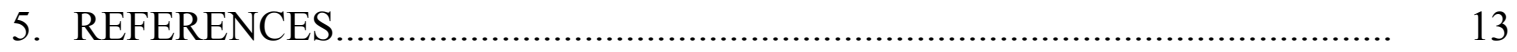





\section{LIST OF TABLES}

Table

1 Mean $( \pm \mathrm{SE})$ pre-disturbance $\mathrm{O}$-horizon $\mathrm{N}$ concentrations and $\mathrm{C}: \mathrm{N}$ ratios at riparian and upland sampling stations in training compartment $\mathrm{K}-11 \ldots .$.

2 Mean $( \pm \mathrm{SE})$ pre-disturbance soil density, $\mathrm{C}$ and $\mathrm{N}$ concentrations, and $\mathrm{C}$ and $\mathrm{N}$ stocks at riparian and upland sites in training compartment $\mathrm{K}-11 \ldots$.

3 Mean $( \pm \mathrm{SE})$ pre-disturbance particulate organic matter $(\mathrm{POM})$, fraction of soil $\mathrm{C}$ in POM and mineral-associated organic matter (MOM), and $\mathrm{C}$ and $\mathrm{N}$ concentrations in $\mathrm{MOM}$ at riparian and upland sites in $\mathrm{K}-11 \ldots \ldots \ldots . . .$.

4 Mean $( \pm \mathrm{SE})$ pre-disturbance $\mathrm{C}$ stocks $\left(\mathrm{g} \mathrm{C} \mathrm{m}^{-2}\right)$ in different soil pools at riparian and upland sites in training compartment $\mathrm{K}-11$.

5 Mean $\left( \pm\right.$ SE) pre-disturbance concentrations of extractable $\mathrm{NH}_{4}-\mathrm{N}, \mathrm{NO}_{3}-\mathrm{N}$ and inorganic $\mathrm{N}$, potential net $\mathrm{N}$ mineralization and nitrification during 12-week aerobic laboratory incubations, and the calculated annual rate of potential net $\mathrm{N}$ mineralization in surface $(0-20 \mathrm{~cm})$ mineral soils from

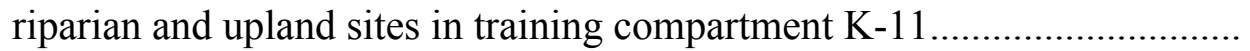

6 Mean $( \pm \mathrm{SE})$ O-horizon properties at upland sites disturbed by a bulldozer and at paired, undisturbed (control) sites in K-11

7 Mean $( \pm \mathrm{SE})$ soil density, $\mathrm{C}$ and $\mathrm{N}$ concentrations, and $\mathrm{C}$ and $\mathrm{N}$ stocks at upland sites disturbed by a bulldozer and at paired, undisturbed (control) sites in training compartment K-11

8 Mean $( \pm$ SE) amounts of particulate organic matter (POM), concentrations of $\mathrm{C}$ and $\mathrm{N}$ in POM and mineral-associated organic matter (MOM), and the fraction of soil $\mathrm{C}$ or $\mathrm{N}$ in POM at upland sites disturbed by a bulldozer and at paired, undisturbed (control) sites in K-11.

9 Mean $( \pm \mathrm{SE})$ post disturbance concentrations of extractable $\mathrm{NH}_{4}-\mathrm{N}$, $\mathrm{NO}_{3}-\mathrm{N}$, and inorganic $\mathrm{N}$, potential net $\mathrm{N}$ mineralization and nitrification during 12-week aerobic laboratory incubations, and the calculated annual rate of potential net $\mathrm{N}$ mineralization in surface $(0-20 \mathrm{~cm})$ mineral soils

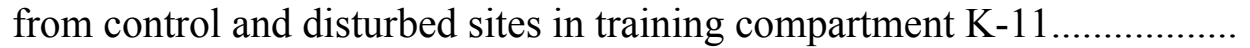





\section{ACKNOWLEDGMENTS}

This research, project number CS-1114D-00, is a part of the Strategic Environmental Research and Development Program (SERDP) Ecosystem Management Project (SEMP) and was sponsored by the U.S. Department of Defense, in partnership with the U.S. Department of Energy and the U.S. Environmental Protection Agency. Oak Ridge National Laboratory (ORNL) is managed by UT-Battelle, LLC, for the U.S. Department of Energy under contract DE-AC0500OR22725. We wish to thank Bonnie Lu (ORNL) and student intern Deanne Brice for their contributions in the laboratory and Robert Washington-Allen for his help with the field work. We thank Hal Balbach, U.S. Army Corps of Engineer Construction Engineering Research Laboratory, for his helpful comments on the draft report. We also wish to acknowledge the gracious assistance of Army personnel located at Fort Benning, especially Hugh Westbury, John Brent, and Pete Swiderek. 



\begin{abstract}
The purpose of this report is to describe the effects of heavy, tracked-vehicle disturbance on various measures of soil quality in training compartment K-11 at Fort Benning, Georgia. Predisturbance soil sampling in April and October of 2002 indicated statistically significant differences in soil properties between upland and riparian sites. Soil density was less at riparian sites, but riparian soils had significantly greater $\mathrm{C}$ and $\mathrm{N}$ concentrations and stocks than upland soils. Most of the $\mathrm{C}$ stock in riparian soils was associated with mineral-associated organic matter (i.e., the silt + clay fraction physically separated from whole mineral soil). Topographic differences in soil $\mathrm{N}$ availability were highly dependent on the time of sampling. Riparian soils had higher concentrations of extractable inorganic $\mathrm{N}$ than upland soils and also exhibited significantly greater soil $\mathrm{N}$ availability during the spring sampling.
\end{abstract}

The disturbance experiment was performed in May 2003 by driving a D7 bulldozer through the mixed pine/hardwood forest. Post-disturbance sampling was limited to upland sites because training with heavy, tracked vehicles at Fort Benning is generally confined to upland soils. Soil sampling approximately one month after the experiment indicated that effects of the bulldozer were limited primarily to the forest floor (O-horizon) and the surface $(0-10 \mathrm{~cm})$ mineral soil. O-horizon dry mass and $\mathrm{C}$ stocks were significantly reduced, relative to undisturbed sites, and there was an indication of reduced mineral soil $\mathrm{C}$ stocks in the disturbance zone. Differences in the surface $(0-10 \mathrm{~cm})$ mineral soil also indicated a significant increase in soil density as a result of disturbance by the bulldozer. Although there was some tendency for greater soil $\mathrm{N}$ availability in disturbed soils, the changes were not significantly different from undisturbed controls. It is expected that repeated soil disturbance over time, which will normally occur in a military training area, would simply intensify the changes in soil properties that were measured following a one-time soil disturbance at the K-11 training compartment.

The experiment was also useful for identifying soil measurements that are particularly sensitive to disturbance and therefore can be used successfully as indicators of a change in soil properties as a result of heavy, tracked-vehicle traffic at Fort Benning. Measurements related to total O-horizon mass and $\mathrm{C}$ concentrations or stocks exhibited changes that ranged from $\approx 25$ to $75 \%$ following the one-time disturbance. Changes in surface $(0-10 \mathrm{~cm})$ mineral soil density or measures of surface soil $\mathrm{C}$ and $\mathrm{N}$ following the disturbance were less remarkable and ranged from $\approx 15$ to $45 \%$ (relative to undisturbed controls). Soil $\mathrm{N}$ availability (measured as initial extractable soil $\mathrm{N}$ or $\mathrm{N}$ production in laboratory incubations) was the least sensitive and the least useful indicator for detecting a change in soil quality. Collectively, the results suggest that the best indicators of a change in soil quality will be found at the soil surface because there were no statistically significant effects of bulldozer disturbance at soil depths below $10 \mathrm{~cm}$.

Key words: soil disturbance, tracked-vehicle training, soil C, soil N, particulate organic matter (POM), soil quality, ecological indicators, military land management 


\section{INTRODUCTION}

Disturbance of soil physical properties and/or structure are commonly reported effects associated with the use of heavy, tracked vehicles in military training (Iverson et al., 1981; Prose, 1985; Braunack, 1986; Thurow et al., 1993; Ayers, 1994; Prosser et al., 2000; Belnap and Warren, 2002). In some environments, it has been shown that the effects of soil disturbance by tracked military vehicles can persist for decades (e.g., Iverson et al., 1981; Belnap and Warren, 2002). At Fort Benning, Georgia, field training with tracked vehicles has resulted in an overall loss of soil quality at some training sites where heavily disturbed, barren soils have negligible Ohorizons, lower soil $\mathrm{N}$ availability, and lower soil $\mathrm{C}$ and $\mathrm{N}$ stocks than soils subject to minimal military use (Garten et al., 2003; Garten and Ashwood, 2004).

The purpose of this report is to describe the effects of heavy, tracked-vehicle disturbance on various measures of soil quality in training compartment K-11 at Fort Benning, Georgia. An experiment was performed by driving a D7 bulldozer through a mixed pine/hardwood forest. Pre-disturbance soil sampling was performed in both spring and autumn of the year preceding the disturbance to determine how site-specific topographic differences in soil quality would potentially affect post-disturbance sampling. The null hypothesis for the experiment was that disturbance caused by a heavy, tracked vehicle would not affect overall forest soil quality by changing soil $\mathrm{C}$ and $\mathrm{N}$ or by changing soil $\mathrm{N}$ availability. The bulldozer was considered here as a surrogate for a military, tracked vehicle of similar weight.

\section{METHODS}

\subsection{STUDY SITE}

The study site was located in the northeast corner of Fort Benning in a mature, secondgrowth, mixed evergreen-hardwood forest in training compartment K-11. The topography at the site included both poorly drained riparian zones adjacent to intermittent streams and welldrained upland forest stands. Forest management practices at the site have been implemented to promote growth and development of long-leaf pine (Pinus palustris).

The site's prior history included light military activity (i.e., infantry training) in addition to stand thinning and prescribed burning as part of the installation's timber management program. Prescribed burning to remove understory shrubs and hardwood saplings occurred in May 2002 and thinning occurred in late October 2002 (6 months prior to the experimental disturbance).

The disturbance was performed in May 2003 with several passes of a D7 bulldozer. The weight of the equipment was approximately $23,000 \mathrm{~kg}$. The disturbance removed existing vegetation and forest floor organic matter from two rectangular areas (approximately $5 \times 50 \mathrm{~m}$ in size). Most surface debris was piled at one end of the bulldozer cut, however a visual inspection 
of the site revealed that a minor part of the surface debris was buried by the disturbance.

\subsection{SOIL SAMPLING}

Pre-disturbance sampling was conducted in April and early October 2002 to characterize seasonal and topographic differences in soil $\mathrm{C}$ and $\mathrm{N}$ and soil $\mathrm{N}$ availability. In April, 16 sampling stations were established along transects that traversed both upland $(n=8)$ and riparian $(\mathrm{n}=8)$ areas. The October sampling was performed at 17 stations ( 7 riparian and 10 upland). Post-disturbance sampling was conducted in June 2003 to characterize the effect of disturbance on soil quality. Results from the pre-disturbance sampling indicated topographic differences in soil properties (see results), therefore post-disturbance soil sampling was limited to upland locations. Seven sampling stations were randomly chosen along the disturbance zone created by the bulldozer. For each upland station in the disturbance zone, a control sampling station was selected in an undisturbed area $\approx 5 \mathrm{~m}$ from the disturbance.

In both pre- and post-disturbance soil sampling, replicate samples of the O-horizon (when present) were removed with a knife from a $214 \mathrm{~cm}^{2}$ area above the mineral soil. Replicate mineral soil samples $(0-30 \mathrm{~cm})$ were then collected in butyrate plastic tubes using a soil probe (2.4 cm diameter) with hammer attachment (AMS, American Falls, ID). The distance between replicate samples was 1 to $2 \mathrm{~m}$. A third sample $(0-20 \mathrm{~cm})$ was also collected at each sampling station by hammering a PVC pipe $(5.1 \mathrm{~cm}$ diam x $25 \mathrm{~cm}$ long) into the mineral soil. The ends of the tubes and the pipes were capped to prevent soil loss during transport. Samples were transported to the laboratory and stored in a refrigerator $\left(5^{\circ} \mathrm{C}\right)$ prior to analysis.

\subsection{SAMPLE ANALYSIS}

\subsubsection{Soil Carbon and Nitrogen}

The dry mass of O-horizon material was determined after oven-drying at $75{ }^{\circ} \mathrm{C}$. Ohorizon samples were ground and homogenized in a sample mill and stored in airtight glass bottles prior to elemental analysis. Mineral soil samples collected in the butyrate tubes were cut into $10 \mathrm{~cm}$ increments and equivalent depth increments from the same sampling station were composited. Soil samples were dried to a constant weight at room temperature $\left(21^{\circ} \mathrm{C}\right)$ in a laboratory equipped with a dehumidifier. The air-dry soil samples were crushed with a rubber mallet and passed through a 2-mm sieve to remove gravel and coarse debris. A subsample of the soil $(<2 \mathrm{~mm})$ was ground and homogenized in a ball mill and stored in an airtight container prior to elemental analysis.

\subsubsection{Physical Fractionation of Soils}

Part of each surface mineral soil sample $(0-20 \mathrm{~cm})$ collected in a PVC pipe was physically separated into particulate organic matter (POM) and mineral-associated organic matter (MOM) (Cambardella and Elliott, 1992). Twenty grams of air-dry soil were dispersed by shaking 
overnight in a $100 \mathrm{~mL}$ solution of sodium hexametaphosphate $\left(5 \mathrm{~g} \mathrm{~L}^{-1}\right)$. The mixture was wetsieved through a $0.053 \mathrm{~mm}$ sieve. POM was recovered by back washing the sieve, filtering (Whatman 541) the POM from the wash solution, and oven drying. The mixture that passed the $0.053 \mathrm{~mm}$ sieve was also oven dried to recover MOM (i.e., silt + clay). Both POM and MOM from each soil sample were weighed after oven drying $\left(75^{\circ} \mathrm{C}\right)$ and stored in airtight containers prior to elemental analysis.

\subsubsection{Soil Nitrogen Availability}

Part of each surface mineral soil sample $(0-20 \mathrm{~cm})$ collected in a PVC pipe was used for the determination of potential net soil $\mathrm{N}$ mineralization and nitrification in 12-week aerobic laboratory incubations. The fresh soil was passed through a $6.3 \mathrm{~mm}$ sieve to remove coarse debris and rocks. A subsample of the sieved soil was air-dried to determine the dry mass-tofresh mass conversion factor. A second subsample of sieved soil $(\approx 12 \mathrm{~g})$ was extracted by shaking for 2 hours in a $100 \mathrm{~mL}$ solution of $2 \mathrm{M} \mathrm{KCl}$ to determine initial extractable $\mathrm{NH}_{4}-\mathrm{N}_{\text {and }}$ $\mathrm{NO}_{3}-\mathrm{N}$. The remaining soil $(<6.3 \mathrm{~mm})$ was placed in a plastic jar and incubated in the dark at room temperature $\left(21^{\circ} \mathrm{C}\right)$. Once a week, the lids were removed briefly from the jars to aerate the soil samples. Extractions of the incubating soils were repeated after 6 and 12 weeks to determine the production of $\mathrm{NH}_{4}-\mathrm{N}$ and $\mathrm{NO}_{3}-\mathrm{N}$. Extractions were allowed to settle overnight in a refrigerator $\left(5^{\circ} \mathrm{C}\right)$. Potential net soil $\mathrm{N}$ mineralization was calculated as the difference between extractable inorganic $\mathrm{N}\left(\mathrm{NH}_{4}-\mathrm{N}+\mathrm{NO}_{3}-\mathrm{N}\right)$ at 6 or 12 weeks and the initial extractable inorganic $\mathrm{N}$. Potential net soil nitrification was calculated in a similar manner from concentrations of extractable $\mathrm{NO}_{3}-\mathrm{N}$. In each case, the units were $\mu \mathrm{g} \mathrm{N} \mathrm{g}^{-1}$ air-dry soil, based the dry mass-to-fresh mass conversion factor from the initial soil sample.

\subsubsection{Elemental Analysis}

Samples were analyzed for total C and N using a LECO CN-2000 (LECO Corporation, St. Joseph, MI). The elemental analyzer was calibrated using LECO standards traceable to the National Institute of Standards and Technology (NIST), Gaithersburg, MD. Soil extracts were analyzed for $\mathrm{NH}_{4}-\mathrm{N}$ and $\mathrm{NO}_{3}-\mathrm{N}$ concentrations by digital colorimetry using a Bran+Luebbe AutoAnalyzer 3.

\subsubsection{Calculations}

Carbon and $\mathrm{N}$ stocks ( $\mathrm{g}$ element $\mathrm{m}^{-2}$ ) in the O-horizon were calculated as the product of concentration ( $\mathrm{g}$ element $\left.\mathrm{g}^{-1}\right)$ and dry mass per unit area $\left(\mathrm{g} \mathrm{m}^{-2}\right)$. Carbon and $\mathrm{N}$ stocks in each increment of mineral soil were calculated as the product of concentration ( $\mathrm{g}$ element $\mathrm{g}^{-1}$ soil), soil density $\left(\mathrm{g} \mathrm{m}^{-3}\right)$, and increment length $(\mathrm{m})$. Soil density was calculated on the basis of air-dry mass $(<2 \mathrm{~mm})$ and the known volume of soil collected in the butyrate plastic tubes.

Soil C in POM (g POM-C g $\mathrm{g}^{-1}$ soil) or MOM (g MOM-C $\mathrm{g}^{-1}$ soil) was calculated by multiplying the dry mass of the POM or MOM part ( $\mathrm{g}$ part $\mathrm{g}^{-1}$ soil) by the respective $\mathrm{C}$ 
concentration ( $\mathrm{g} \mathrm{C} \mathrm{g}^{-1}$ part). The fraction of soil $\mathrm{C}$ in POM (fPOM) was calculated based on the total $\mathrm{C}$ measured in the POM and MOM. The $\mathrm{C}$ stock in surface mineral soil that was associated with POM (POM-C) was calculated as the product of soil C stock $\left(\mathrm{g} \mathrm{C} \mathrm{m}^{-2}\right)$ and fPOM. The $\mathrm{C}$ stock in surface mineral soil that was associated with MOM (MOM-C) was calculated as the product of soil $\mathrm{C}$ stock $\left(\mathrm{g} \mathrm{C} \mathrm{m}^{-2}\right)$ and $(1-\mathrm{fPOM})$. Following appropriate substitutions in the equations, similar calculations were performed for soil $\mathrm{N}$.

The annual potential rate of net soil $\mathrm{N}$ mineralization was calculated by extrapolating the net $\mathrm{N}$ mineralization in 12-week aerobic laboratory incubations to 52 weeks $\left(\mathrm{g} \mathrm{N}\right.$ produced g ${ }^{-1}$ soil) and dividing by the surface $(0-20 \mathrm{~cm})$ soil $\mathrm{N}$ concentration $\left(\mathrm{g} \mathrm{N} \mathrm{g}^{-1}\right)$. This calculation provides an estimate of the fraction of organic soil $\mathrm{N}$ that is potentially mineralized each year.

\subsubsection{Statistical Analysis}

Although pre- and post-disturbance soil sampling occurred in the same general area, the two data sets were not directly comparable because sampling was not undertaken at precisely the same locations. Measurements on pre-disturbance soil samples were analyzed for seasonal (April vs. October) and topographic (riparian vs. upland) differences using two-way ANOVA. If one of the main effects and the interaction were not statistically significant, the analysis was simplified to a one-way ANOVA in which the statistically significant main effect was retained. Post-hoc tests of differences between means were performed using Fisher's protected least significant difference (LSD). The results of pre-disturbance soil sampling was used for planning post-disturbance sampling. Post-disturbance soil samples were limited to upland sites and were analyzed for the effects of bulldozer disturbance using a paired t-test (each disturbance sampling station was paired with an undisturbed control station). Unless stated otherwise, statistical significance was indicated by $P \leq 0.05$.

\section{RESULTS}

\subsection{PRE-DISTURBANCE SOIL SAMPLING}

\subsubsection{O-Horizon}

There were no significant differences between sampling dates (April and October) for Ohorizon measurements in training compartment K-11. Mean \pm SE O-horizon dry mass in the pre-disturbance soil sampling was $1246 \pm 78 \mathrm{~g} \mathrm{~m}^{-2}(\mathrm{n}=33)$. The mean \pm SE O-horizon $\mathrm{C}$ and $\mathrm{N}$ stocks were $490 \pm 35(\mathrm{n}=33)$ and $9.1 \pm 0.8(\mathrm{n}=33) \mathrm{g} \mathrm{m}^{-2}$, respectively. There were no significant topographic differences in $\mathrm{O}$-horizon $\mathrm{C}$ and $\mathrm{N}$ stocks despite a significant difference between riparian and upland sampling stations in O-horizon $\mathrm{N}$ concentrations and $\mathrm{C}: \mathrm{N}$ ratios (Table 1). The O-horizon $\mathrm{N}$ concentration was significantly less and the $\mathrm{C}: \mathrm{N}$ ratio was significantly greater at upland sampling stations. 
Table 1. Mean ( \pm SE) pre-disturbance $O$-horizon $N$ concentrations and $C: N$ ratios at riparian and upland sampling stations in training compartment $\mathrm{K}-11$.

The number of sampling stations is shown in parenthesis.

\begin{tabular}{|c|c|c|c|}
\hline \multirow{2}{*}{ Variable } & \multicolumn{2}{|c|}{ Sampling stations } & \multirow{2}{*}{ F-value $^{\mathrm{a}}$} \\
\cline { 2 - 3 } & Riparian $(\mathrm{n}=15)$ & Upland $(\mathrm{n}=18)$ & $5.2^{*}$ \\
\hline N concentration (\%) & $0.814 \pm 0.044$ & $0.656 \pm 0.051$ & $5.4^{*}$ \\
\hline C:N ratio & $49.4 \pm 1.8$ & $70.1 \pm 8.0$ & \\
\hline $\begin{array}{l}{ }^{2} \text { Degrees of freedom }=1,31 \\
* P \leq 0.05\end{array}$ \\
\hline
\end{tabular}

\subsubsection{Whole Mineral Soil}

Sampling date had no significant effect on soil $\mathrm{C}$ or soil $\mathrm{N}$ concentrations in any of the mineral soil depth increments examined $(0-10,10-20$, and 20-30 cm). However, there were significant differences in soil density, soil $\mathrm{C}$ and $\mathrm{N}$ concentrations, and soil $\mathrm{C}$ and $\mathrm{N}$ stocks between upland and riparian sites in training compartment K-11 (Table 2). Although riparian zones had significantly lower soil densities than upland areas, there was significantly more soil $\mathrm{C}$ and $\mathrm{N}$ in riparian zones because of large differences in soil $\mathrm{C}$ and $\mathrm{N}$ concentrations.

In general, soil $\mathrm{C}$ and $\mathrm{N}$ concentrations at riparian sampling stations were a factor of 2 or more greater than those at upland sampling stations. Mean $\pm \mathrm{SE} \mathrm{C}$ stocks over the top $30 \mathrm{~cm}$ of mineral soil were $5609 \pm 367$ and $2748 \pm 131 \mathrm{~g} \mathrm{C} \mathrm{m}^{-2}$ in riparian and upland soils, respectively. Mean \pm SE soil N stocks over the top $30 \mathrm{~cm}$ of mineral soil were $174 \pm 14 \mathrm{~g} \mathrm{~N} \mathrm{~m}^{-2}$ at the riparian stations and $85.4 \pm 7.2 \mathrm{~g} \mathrm{~N} \mathrm{~m}^{-2}$ at the upland stations. Topographic position had no significant effect on soil C:N ratios at any soil depth. The mean $\pm \mathrm{SE} \mathrm{C:N}$ ratios for the $0-10,10-20$, and 20-30 $\mathrm{cm}$ soil increments $(\mathrm{n}=33$ samples for each depth) were, respectively, $33.6 \pm 1.2,37.4$ \pm 2.3 , and $38.7 \pm 5.0$.

\subsubsection{Physical Fractionation of Soils}

None of the measurements associated with the physical separation of whole soil $\mathrm{C}$ or $\mathrm{N}$ between POM and MOM were significantly affected by sampling date. There were significant differences between riparian and upland sampling stations for measured amounts of POM and MOM, the fraction of soil C in POM (fPOM) and MOM (fMOM), and concentrations of C and $\mathrm{N}$ in MOM (Table 3). Soils from upland stations had greater amounts of POM and a greater fraction of soil $\mathrm{C}$ in POM. Riparian soils had greater $\mathrm{C}$ and $\mathrm{N}$ concentrations in MOM than soils from upland stations.

Soils from riparian sampling stations had significantly greater total soil $\mathrm{C}$ stocks and more $\mathrm{C}$ in POM and MOM than soils from upland sampling stations (Table 4). Carbon in the Ohorizon and POM was summed to approximate labile soil $\mathrm{C}$ which was significantly greater in 
riparian soils than in upland soils (due to differences in amounts of POM-C). At riparian and upland sites, respectively, $\approx 62$ and $49 \%$ of the total soil $\mathrm{C}$ was associated with MOM indicating greater relative amounts of stabilized soil $\mathrm{C}$ pool in areas adjacent to streams.

\begin{tabular}{|c|c|c|c|c|}
\hline \multirow[b]{2}{*}{ Variable } & \multirow{2}{*}{$\begin{array}{l}\text { Soil depth } \\
\quad(\mathrm{cm})\end{array}$} & \multicolumn{2}{|c|}{ Sampling stations } & \multirow{2}{*}{ F-value $^{a}$} \\
\hline & & Riparian $(n=15)$ & Upland $(\mathrm{n}=18)$ & \\
\hline \multirow[t]{3}{*}{ Soil density $\left(\mathrm{g} \mathrm{cm}^{-3}\right)$} & $0-10$ & $0.972 \pm 0.025$ & $1.143 \pm 0.034$ & $15.6 * * *$ \\
\hline & $10-20$ & $1.245 \pm 0.028$ & $1.382 \pm 0.020$ & $16.8 * * *$ \\
\hline & $20-30$ & $1.367 \pm 0.035$ & $1.441 \pm 0.022$ & NS \\
\hline \multirow[t]{3}{*}{ Soil C concentration $(\%)$} & $0-10$ & $2.97 \pm 0.25$ & $1.45 \pm 0.09$ & $37.1 * * *$ \\
\hline & $10-20$ & $1.32 \pm 0.12$ & $0.50 \pm 0.03$ & $49.9 * * *$ \\
\hline & $20-30$ & $0.89 \pm 0.12$ & $0.29 \pm 0.02$ & $28.5 * * *$ \\
\hline \multirow[t]{3}{*}{ Soil C stock $\left(\mathrm{g} \mathrm{C} \mathrm{m}^{-2}\right)$} & $0-10$ & $2821 \pm 196$ & $1638 \pm 96$ & $32.5 * * *$ \\
\hline & $10-20$ & $1612 \pm 123$ & $694 \pm 43$ & $56.9 * * *$ \\
\hline & $20-30$ & $1176 \pm 129$ & $415 \pm 31$ & $39.1 * * *$ \\
\hline \multirow[t]{3}{*}{ Soil $N$ concentration $(\%)$} & $0-10$ & $0.092 \pm 0.008$ & $0.044 \pm 0.015$ & $32.2 * * *$ \\
\hline & $10-20$ & $0.039 \pm 0.004$ & $0.015 \pm 0.001$ & $34.2 * * *$ \\
\hline & $20-30$ & $0.030 \pm 0.006$ & $0.009 \pm 0.001$ & $13.9 * * *$ \\
\hline \multirow[t]{3}{*}{ Soil N stock $\left(\mathrm{g} \mathrm{N} \mathrm{m}^{-2}\right)$} & $0-10$ & $88.4 \pm 6.9$ & $50.7 \pm 4.2$ & $23.3 * * *$ \\
\hline & $10-20$ & $47.1 \pm 4.1$ & $21.0 \pm 2.1$ & $34.8 * * *$ \\
\hline & $20-30$ & $38.9 \pm 6.3$ & $13.7 \pm 1.7$ & $17.3 * * *$ \\
\hline \multicolumn{5}{|c|}{$\begin{array}{l}{ }^{\mathrm{a}} \text { Degrees of freedom }=1,31 \\
* * * P \leq 0.001 ; \mathrm{NS}=\text { not significantly different }\end{array}$} \\
\hline
\end{tabular}

\subsubsection{Soil Nitrogen Availability}

There was no effect of sampling date on initial extractable $\mathrm{NH}_{4}-\mathrm{N}, \mathrm{NO}_{3}-\mathrm{N}$ and inorganic $\mathrm{N}$ in pre-disturbance soil samples from training compartment K-11. For this reason, extraction data from April and October were combined prior to a comparison of riparian and upland soils. Extractable $\mathrm{NH}_{4}-\mathrm{N}$ and inorganic-N were significantly greater in soils from riparian sampling stations (Table 5). At both riparian and upland sites, extractable $\mathrm{NO}_{3}-\mathrm{N}$ was a small percentage $(\leq 3 \%)$ of initial extractable inorganic soil N.

There were complex interactions between time of sampling and sampling location for 
measurements of both potential net soil $\mathrm{N}$ mineralization and nitrification (Table 5). In April, riparian soils exhibited more potential net soil $\mathrm{N}$ mineralization than upland soils, but there was no significant difference in October soil samples. Potential net nitrification was significantly greater in riparian soils than upland soils in both April and October (although there was a 10\% probability that the difference in April samples was due to chance alone). When data from the April sampling period were used, calculated potential rates of net $\mathrm{N}$ mineralization in riparian soils were significantly greater than those in upland soils. However, when data from the October sampling period were used, there was no statistically significant difference between riparian and upland sites.

\begin{tabular}{|c|c|c|c|}
\hline \multirow[b]{2}{*}{ Variable } & \multicolumn{2}{|c|}{ Sampling stations } & \multirow[b]{2}{*}{ F-value $^{a}$} \\
\hline & Riparian $(\mathrm{n}=15)$ & Upland $(\mathrm{n}=18)$ & \\
\hline POM (g POM g goil) & $0.772 \pm 0.024$ & $0.841 \pm 0.008$ & $8.3 * *$ \\
\hline Fraction of soil $\mathrm{C}$ in $\mathrm{POM}$ & $0.317 \pm 0.018$ & $0.406 \pm 0.014$ & $15.2 * *$ \\
\hline Fraction of soil $\mathrm{C}$ in $\mathrm{MOM}$ & $0.683 \pm 0.018$ & $0.594 \pm 0.014$ & $15.2 * *$ \\
\hline $\mathrm{C}$ concentration in $\mathrm{MOM}(\%)$ & $6.44 \pm 0.51$ & $4.08 \pm 0.28$ & $17.9^{* * *}$ \\
\hline $\mathrm{N}$ concentration in $\mathrm{MOM}(\%)$ & $0.268 \pm 0.020$ & $0.174 \pm 0.013$ & $16.4 * * *$ \\
\hline \multicolumn{4}{|l|}{$\begin{array}{l}{ }^{\mathrm{a}} \text { Degrees of freedom }=1,31 \\
* * P \leq 0.01 ; * * * P \leq 0.001\end{array}$} \\
\hline
\end{tabular}

Table 4. Mean ( \pm SE) pre-disturbance $C$ stocks $\left(\mathrm{g} \mathrm{C} \mathrm{m}^{-2}\right)$ in different soil pools at riparian and upland sites in training compartment $K-11$.

The number of sampling stations is shown in parenthesis.

\begin{tabular}{|c|c|c|c|}
\hline \multirow[b]{2}{*}{ Soil C pool } & \multicolumn{2}{|c|}{ Sampling stations } & \multirow[b]{2}{*}{ F-value ${ }^{a}$} \\
\hline & Riparian $(\mathrm{n}=15)$ & Upland $(\mathrm{n}=18)$ & \\
\hline O-horizon & $455 \pm 56$ & $519 \pm 46$ & NS \\
\hline Particulate organic matter (POM) & $1404 \pm 117$ & $950 \pm 62$ & $12.9 * *$ \\
\hline Labile organic matter & $1859 \pm 146$ & $1469 \pm 93$ & $5.4^{*}$ \\
\hline Mineral-associated organic matter & $3028 \pm 215$ & $1382 \pm 76$ & $59.9 * * *$ \\
\hline Total $^{\mathrm{b}}$ & $4888 \pm 311$ & $2851 \pm 132$ & $40.9 * * *$ \\
\hline \multicolumn{4}{|c|}{$\begin{array}{l}\text { a Degress of freedom }=1,31 \\
\text { b } 20 \mathrm{~cm} \text { soil depth } \\
{ }^{*} P \leq 0.05 ; * * P \leq 0.01 ; * * * P \leq 0.001 ; \mathrm{NS}=\text { not significantly different }\end{array}$} \\
\hline
\end{tabular}




\begin{tabular}{|c|c|c|c|c|}
\hline \multicolumn{5}{|c|}{$\begin{array}{l}\text { Table 5. Mean ( } \pm \text { SE) pre-disturbance concentrations of extractable } \mathrm{NH} \\
\text { inorganic } \mathrm{N} \text {, potential net } \mathrm{N} \text { mineralization and nitrification during a } 1 \\
\text { laboratory incubations, and the calculated annual rate of potential net } \\
\text { in surface }(0-20 \mathrm{~cm}) \text { mineral soils from riparian and upland sites } \\
\text { compartment } \mathrm{K}-11 \text {. } \\
\text { The number of sampling stations is shown in parenthesis. }\end{array}$} \\
\hline \multirow[b]{2}{*}{ Variable } & \multirow{2}{*}{$\begin{array}{l}\text { Sampling } \\
\text { Date }\end{array}$} & \multicolumn{2}{|c|}{ Sampling stations } & \multirow[b]{2}{*}{ F-value } \\
\hline & & Riparian & Upland & \\
\hline Extractable $\mathrm{NH}_{4}-\mathrm{N}\left(\mu \mathrm{g} \mathrm{g}^{-1}\right)$ & -- & $3.8 \pm 0.5(15)$ & $1.7 \pm 0.3(18)$ & $14.3 * * *$ \\
\hline Extractable $\mathrm{NO}_{3}-\mathrm{N}\left(\mu \mathrm{g} \mathrm{g}^{-1}\right)$ & -- & $0.09 \pm 0.030(15)$ & $0.05 \pm 0.02(18)$ & NS \\
\hline Extractable inorganic $\mathrm{N}\left(\mu \mathrm{g} \mathrm{g}^{-1}\right)$ & -- & $3.9 \pm 0.5(15)$ & $1.8 \pm 0.3(18)$ & $14.9 * * *$ \\
\hline \multirow{2}{*}{$\begin{array}{l}\text { Net soil } \mathrm{N} \text { mineralization } \\
\left(\mu \mathrm{g} \mathrm{N} \mathrm{g}^{-1}\right)\end{array}$} & April & $13.3 \pm 3.9(8)$ & $0.8 \pm 0.5(8)$ & $10.0 * *$ \\
\hline & October & $1.3 \pm 1.3(7)$ & $1.8 \pm 0.5(10)$ & NS \\
\hline \multirow{2}{*}{$\begin{array}{l}\text { Net nitrification } \\
\quad\left(\mu \mathrm{g} \mathrm{N} \mathrm{g}^{-1}\right)\end{array}$} & April & $9.1 \pm 4.0(8)$ & $1.3 \pm 0.6(8)$ & $3.7^{\dagger}$ \\
\hline & October & $2.1 \pm 0.9(7)$ & $0.3 \pm 0.2(10)$ & $5.0 *$ \\
\hline \multirow{2}{*}{$\begin{array}{l}\text { Net } \mathrm{N} \text { mineralization rate } \\
\qquad\left(\mathrm{yr}^{-1}\right)\end{array}$} & April & $0.080 \pm 0.015(8)$ & $0.014 \pm 0.008(8)$ & $14.9 * *$ \\
\hline & October & $0.008 \pm 0.008(7)$ & $0.027 \pm 0.009(10)$ & NS \\
\hline
\end{tabular}

\subsection{POST-DISTURBANCE SOIL SAMPLING}

\subsubsection{O-Horizon}

Multiple properties of the forest floor were affected by the experimental disturbance (Table 6). Measurements of O-horizon dry mass, $\mathrm{C}$ concentrations and stocks, $\mathrm{N}$ stocks, and $\mathrm{C}: \mathrm{N}$ ratios were significantly reduced at sampling points in the disturbance zone relative to paired controls. The disturbance reduced O-horizon dry mass by $\approx 60 \%$ and $\mathrm{C}$ stocks by $\approx 71 \%$. $\mathrm{O}$-horizon $\mathrm{N}$ concentration was the only forest floor measurement not significantly affected by the experimental disturbance.

Mean O-horizon dry mass measured at upland control points during post-disturbance sampling $\left(640 \mathrm{~g} \mathrm{~m}^{-2}\right)$ was approximately half that measured in pre-disturbance sampling (1246 $\mathrm{g}$ $\left.\mathrm{m}^{-2}\right)$. Similarly, mean post-disturbance stocks of $\mathrm{C}\left(310 \mathrm{~g} \mathrm{C} \mathrm{m}^{-2}\right)$ and $\mathrm{N}\left(3.19 \mathrm{~g} \mathrm{~N} \mathrm{~m}^{-2}\right)$ in the Ohorizon at control sampling points were $\approx 37$ and $65 \%$ less, respectively, than those measured during pre-disturbance soil sampling. The pre- and post-disturbance differences were not unexpected because a prescribed fire removed understory vegetation and O-horizons from the K11 training compartment prior to the experimental disturbance. Lower O-horizon $\mathrm{N}$ concentrations $(0.51 \pm 0.03 \%)$ in post-disturbance samples indicated that $\mathrm{N}$ losses from fire 
partly contributed to an observed post-disturbance increase in O-horizon C:N ratios.

\begin{tabular}{|c|c|c|c|c|}
\hline \multirow[b]{2}{*}{ Measurement } & \multicolumn{2}{|c|}{ Treatment } & \multirow[b]{2}{*}{$\begin{array}{c}\text { Mean } \\
\text { difference }\end{array}$} & \multirow[b]{2}{*}{$\begin{array}{l}\text { Paired } \\
\text { t-value }\end{array}$} \\
\hline & $\begin{array}{l}\text { Control } \\
(\mathrm{n}=14)\end{array}$ & $\begin{array}{c}\text { Disturbed } \\
(\mathrm{n}=14)\end{array}$ & & \\
\hline Dry mass $\left(\mathrm{g} \mathrm{cm}^{-2}\right)$ & $640 \pm 57$ & $257 \pm 112$ & -384 & $3.26 * *$ \\
\hline C concentration $(\%)$ & $47.8 \pm 0.9$ & $36.7 \pm 1.5$ & -12.9 & $9.19 * * *$ \\
\hline $\mathrm{C}: \mathrm{N}$ ratio & $100.5 \pm 7.5$ & $73.5 \pm 8.7$ & -36.2 & $4.5 * *$ \\
\hline C stock $\left(\mathrm{g} \mathrm{C} \mathrm{m}^{-2}\right)$ & $310 \pm 30$ & $91 \pm 38$ & -219 & $4.9 * * *$ \\
\hline $\mathrm{N}$ stock $\left(\mathrm{g} \mathrm{N} \mathrm{m}^{-2}\right)$ & $3.19 \pm 0.34$ & $1.39 \pm 0.60$ & -1.81 & $2.9 *$ \\
\hline \multicolumn{5}{|c|}{$* P \leq 0.05 ; * * P \leq 0.01 ; * * * P \leq 0.001$} \\
\hline
\end{tabular}

\subsubsection{Whole Mineral Soil}

The effects of bulldozer disturbance on mineral soil properties are presented in Table 7. Disturbance significantly increased soil density in the $0-10 \mathrm{~cm}$ depth increment, but differences between control and disturbed sites were not statistically significant for the 10-20 and 20-30 cm soil increments. Throughout the soil profile, there was a decrease in soil $\mathrm{C}$ concentrations in the disturbance zone, and for each depth increment there was a $10 \%$ probability that the differences occurred by chance alone. Surface $(0-10 \mathrm{~cm})$ soil $\mathrm{C}$ stocks and $\mathrm{N}$ concentrations in the disturbance zone were also reduced by $\approx 37$ and $40 \%$, respectively, relative to control sampling points. Although there was a tendency for lower soil $\mathrm{N}$ stocks at disturbed sites relative to control sites, the differences were not statistically significant.

Post-disturbance soil density at control sites $\left(1.13 \mathrm{~g} \mathrm{~cm}^{-3}\right)$ was similar pre-disturbance soil density at upland sites $\left(1.14 \mathrm{~g} \mathrm{~cm}^{-3}\right)$ in the $\mathrm{K}-11$ training compartment. Although not directly comparable, pre-disturbance soil $\mathrm{C}$ concentrations $(1.45 \%)$ and stocks $\left(1638 \mathrm{~g} \mathrm{C} \mathrm{m}^{-2}\right)$ were more similar to soil $\mathrm{C}$ concentrations $(1.50 \%)$ and stocks $\left(1931 \mathrm{~g} \mathrm{C} \mathrm{m}^{-2}\right)$ in the disturbance zone and less than soil $\mathrm{C}$ concentrations $(2.71 \%)$ and stocks $\left(3041 \mathrm{~g} \mathrm{C} \mathrm{m}^{-2}\right)$ measured at control sites during post-disturbance soil sampling (Table 7).

\subsubsection{Physical Fractionation of Soil}

Post-disturbance sampling indicated no differences between control and bulldozer disturbed sites in the amount of POM in surface mineral soils (Table 8). The amount of POM present was similar to that measured in pre-disturbance surface mineral soil samples from upland sampling sites (i.e., $0.841 \mathrm{~g} \mathrm{POM} \mathrm{g}^{-1}$ soil). Although concentrations of $\mathrm{C}$ and $\mathrm{N}$ in both POM 
and MOM tended to be less in soils from the area disturbed by the bulldozer, the differences were not significantly different. However, the fraction of soil $\mathrm{C}$ and $\mathrm{N}$ in POM (i.e., POM C and $\mathrm{N}$ expressed relative to total soil $\mathrm{C}$ and $\mathrm{N}$ ) was significantly reduced in surface mineral soils under the disturbance (Table 8). Compared to controls, the fraction of soil $\mathrm{C}$ and $\mathrm{N}$ in the POM part was reduced by $\approx 20 \%$ and $\approx 32 \%$, respectively, in soils from the disturbance zone.

\begin{tabular}{|c|c|c|c|c|c|}
\hline \multirow[b]{2}{*}{ Measurement } & \multirow{2}{*}{$\begin{array}{c}\text { Soil } \\
\text { depth } \\
(\mathrm{cm})\end{array}$} & \multicolumn{2}{|c|}{ Treatment } & \multirow[b]{2}{*}{$\begin{array}{c}\text { Mean } \\
\text { difference }\end{array}$} & \multirow[b]{2}{*}{$\begin{array}{l}\text { Paired } \\
\text { t-value }\end{array}$} \\
\hline & & $\begin{array}{l}\text { Control } \\
(n=7)\end{array}$ & $\begin{array}{l}\text { Disturbed } \\
\quad(\mathrm{n}=7)\end{array}$ & & \\
\hline \multirow[t]{3}{*}{ Soil density $\left(\mathrm{g} \mathrm{cm}^{-3}\right)$} & $0-10$ & $1.13 \pm 0.03$ & $1.32 \pm 0.05$ & 0.18 & $2.74^{*}$ \\
\hline & $10-20$ & $1.41 \pm 0.06$ & $1.48 \pm 0.05$ & 0.08 & NS \\
\hline & $20-30$ & $1.54 \pm 0.05$ & $1.57 \pm 0.02$ & 0.03 & NS \\
\hline \multirow[t]{3}{*}{$\mathrm{C}$ concentration $(\%)$} & $0-10$ & $2.71 \pm 0.41$ & $1.50 \pm 0.31$ & -1.20 & $2.35^{\dagger}$ \\
\hline & $10-20$ & $0.66 \pm 0.11$ & $0.45 \pm 0.37$ & -0.21 & $2.37^{\dagger}$ \\
\hline & $20-30$ & $0.43 \pm 0.09$ & $0.23 \pm 0.03$ & -0.20 & $2.10^{\dagger}$ \\
\hline \multirow[t]{3}{*}{$\mathrm{N}$ concentration $(\%)$} & $0-10$ & $0.055 \pm 0.008$ & $0.033 \pm 0.007$ & -0.022 & $1.99^{\dagger}$ \\
\hline & $10-20$ & $0.010 \pm 0.003$ & $0.006 \pm 0.003$ & -0.004 & NS \\
\hline & $20-30$ & $0.004 \pm 0.001$ & $0.003 \pm 0.001$ & -0.001 & NS \\
\hline \multirow[t]{3}{*}{$\mathrm{C}$ stock $\left(\mathrm{g} \mathrm{C} \mathrm{m}^{-2}\right)$} & $0-10$ & $3041 \pm 450$ & $1931 \pm 356$ & -1110 & $2.05^{\dagger}$ \\
\hline & $10-20$ & $909 \pm 114$ & $654 \pm 184$ & -255 & NS \\
\hline & $20-30$ & $658 \pm 140$ & $366 \pm 53$ & -292 & $1.98^{\dagger}$ \\
\hline \multirow[t]{3}{*}{$\mathrm{N}$ stock $\left(\mathrm{g} \mathrm{N} \mathrm{m}^{-2}\right)$} & $0-10$ & $62.0 \pm 9.4$ & $41.5 \pm 7.9$ & -20.5 & NS \\
\hline & $10-20$ & $13.4 \pm 3.8$ & $8.5 \pm 4.2$ & -4.9 & NS \\
\hline & $20-30$ & $5.2 \pm 2.1$ & $4.1 \pm 1.5$ & -1.1 & NS \\
\hline
\end{tabular}

\subsubsection{Soil Nitrogen Availability}

The effects of bulldozer disturbance on measures of soil $\mathrm{N}$ availability are presented in Table 9. Although there was a tendency for greater amounts of extractable soil $\mathrm{N}$ and greater amounts of net soil $\mathrm{N}$ mineralization and nitrification in samples from the disturbance zone, the differences were not significantly different from undisturbed (control) samples. There was a high degree of variability that overshadowed differences in post-disturbance measures of surface $(0-20$ 
Table 8. Mean $( \pm$ SE) amounts of particulate organic matter $(P O M)$, concentrations of $\mathrm{C}$ and $\mathrm{N}$ in POM and mineral-associated organic matter (MOM), and the fraction of soil $\mathrm{C}$ or $\mathrm{N}$ in POM at upland sites disturbed by a bulldozer and at paired, undisturbed (control) sites in K-11.

The number of sampling stations is shown in parenthesis.

\begin{tabular}{|c|c|c|c|c|}
\hline \multirow[b]{2}{*}{ Measurement } & \multicolumn{2}{|c|}{ Treatment } & \multirow[b]{2}{*}{$\begin{array}{c}\text { Mean } \\
\text { difference }\end{array}$} & \multirow[b]{2}{*}{$\begin{array}{l}\text { Paired } \\
\text { t-value }\end{array}$} \\
\hline & $\begin{array}{l}\text { Control } \\
(\mathrm{n}=7)\end{array}$ & $\begin{array}{l}\text { Disturbed } \\
(\mathrm{n}=7)\end{array}$ & & \\
\hline $\begin{array}{l}\text { Particulate organic matter } \\
\qquad\left(\mathrm{g} P O M ~ g^{-1} \text { soil }\right)\end{array}$ & $0.847 \pm 0.005$ & $0.831 \pm 0.016$ & -0.016 & NS \\
\hline POM C concentration $(\%)$ & $0.79 \pm 0.05$ & $0.61 \pm 0.16$ & -0.18 & NS \\
\hline MOM C concentration $(\%)$ & $5.19 \pm 0.30$ & $4.91 \pm 1.01$ & -0.28 & NS \\
\hline Fraction soil $\mathrm{C}$ in $\mathrm{POM}$ & $0.457 \pm 0.016$ & $0.368 \pm 0.032$ & -0.090 & $4.3 * *$ \\
\hline POM N concentration $(\%)$ & $0.014 \pm 0.002$ & $0.009 \pm 0.003$ & -0.004 & NS \\
\hline MOM N concentration $(\%)$ & $0.220 \pm 0.019$ & $0.200 \pm 0.041$ & -0.020 & NS \\
\hline Fraction soil $\mathrm{N}$ in POM & $0.248 \pm 0.027$ & $0.168 \pm 0.033$ & -0.080 & $2.8^{*}$ \\
\hline
\end{tabular}

Table 9. Mean ( \pm SE) post-disturbance concentrations of extractable $\mathrm{NH}_{4}-\mathrm{N}, \mathrm{NO}_{3}-\mathrm{N}$, and inorganic $\mathrm{N}$, potential net $\mathrm{N}$ mineralization and nitrification during a 12-week aerobic laboratory incubations, and the calculated annual rate of potential net $\mathrm{N}$ mineralization in surface $(0-20 \mathrm{~cm})$ mineral soils from control and disturbed sites in training compartment K-11.

The number of sampling stations is shown in parenthesis.

\begin{tabular}{|c|c|c|c|c|}
\hline \multirow[b]{2}{*}{ Measurement } & \multicolumn{2}{|c|}{ Treatment } & \multirow[b]{2}{*}{$\begin{array}{c}\text { Mean } \\
\text { difference }\end{array}$} & \multirow[b]{2}{*}{$\begin{array}{l}\text { Paired } \\
\text { t-value }\end{array}$} \\
\hline & $\begin{array}{l}\text { Control } \\
(\mathrm{n}=7)\end{array}$ & $\begin{array}{l}\text { Disturbed } \\
\quad(\mathrm{n}=7)\end{array}$ & & \\
\hline Extractable $\mathrm{NH}_{4}-\mathrm{N}\left(\mu \mathrm{g} \mathrm{g}^{-1}\right)$ & $2.9 \pm 0.9$ & $3.0 \pm 1.3$ & 0.1 & NS \\
\hline Extractable $\mathrm{NO}_{3}-\mathrm{N}\left(\mu \mathrm{g} \mathrm{g}^{-1}\right)$ & $0.0 \pm 0.0$ & $0.6 \pm 0.5$ & 0.6 & NS \\
\hline Extractable inorganic $\mathrm{N}\left(\mu \mathrm{g} \mathrm{g}^{-1}\right)$ & $2.9 \pm 0.9$ & $3.6 \pm 1.6$ & 0.7 & NS \\
\hline Net soil $\mathrm{N}$ mineralization $\left(\mu \mathrm{g} \mathrm{N} \mathrm{g}^{-1}\right)$ & $6.0 \pm 2.4$ & $9.6 \pm 5.8$ & 3.6 & NS \\
\hline Net nitrification $\left(\mu \mathrm{g} \mathrm{N} \mathrm{g}^{-1}\right)$ & $8.1 \pm 3.3$ & $12.1 \pm 7.0$ & 4.0 & NS \\
\hline Net $\mathrm{N}$ mineralization rate $\left(\mathrm{yr}^{-1}\right)$ & $0.058 \pm 0.022$ & $0.067 \pm 0.036$ & 0.013 & NS \\
\hline
\end{tabular}


$\mathrm{cm}$ ) soil $\mathrm{N}$ availability. The calculated annual rates of net soil $\mathrm{N}$ mineralization, which were normalized for the amount of soil $\mathrm{N}$ present in each sample, were intermediate between rates measured for riparian $\left(0.08 \mathrm{yr}^{-1}\right)$ and upland $\left(0.014 \mathrm{yr}^{-1}\right)$ soils during pre-disturbance soil sampling in April 2002.

\section{DISCUSSION}

Pre-disturbance sampling revealed that site-specific, topographic differences in soil properties could potentially influence the interpretation of data from the disturbance experiment. In particular, there were major differences between riparian and upland sites that existed prior to the experimental disturbance. Soils from riparian areas in compartment K-11 had greater total C stocks and greater amounts of $\mathrm{C}$ in different soil parts (e.g., POM and MOM). In addition, a larger amount of $\mathrm{C}$ was associated with MOM in riparian soils than in upland soils. Topographic differences in $\mathrm{N}$ availability were also indicated by the incubation of predisturbance samples with a tendency toward higher $\mathrm{N}$ availability in riparian soils. The latter difference was, however, highly dependent on the time of soil sampling. Other than the effect on soil $\mathrm{N}$ availability, time of sampling made no difference to the interpretation of data from predisturbance soil samples. Greater amounts of $\mathrm{C}$ and $\mathrm{N}$ in riparian soils may be caused by depositional processes that move organic matter and nutrients from upland areas to riparian zones as well as higher levels of soil moisture in riparian zones that can inhibit decomposition of soil organic matter. Greater soil $\mathrm{N}$ availability in riparian zones at training compartment $\mathrm{K}-11$ is consistent with results from other research that has examined topographic variation in forest soil $\mathrm{N}$ dynamics (Garten et al., 1994).

The forest at the experimental site was both thinned of trees and subjected to a prescribed burn prior to disturbance by the D7 bulldozer. In general, forest harvesting and prescribed fires have little or no effect on forest mineral soil C and N (Johnson and Curtis, 2001; Wan et al. 2001). Thinning and burning complicated planned pre- and post-disturbance comparisons of the bulldozer's effect on measures of soil quality, however their occurrence probably had no effect on paired comparisons between undisturbed and disturbed soils at upland sampling sites where soils were subjected to the same pre-disturbance forest management practices. Post-disturbance sampling was limited to upland sites in the K-11 training compartment because training with heavy, tracked vehicles at Fort Benning is generally confined to upland soils.

Soil sampling approximately one month after the experimental disturbance indicated that effects of the bulldozer were limited primarily to the forest floor (O-horizon) and the surface ( 0 $10 \mathrm{~cm}$ ) mineral soil. O-horizon dry mass and $\mathrm{C}$ stocks were significantly reduced, relative to undisturbed sites, and there was an indication of reduced mineral soil $\mathrm{C}$ stocks in the disturbance zone. Differences in the surface $(0-10 \mathrm{~cm})$ mineral soil also indicated a significant increase in soil compaction (i.e., soil density) as a result of disturbance with the bulldozer. However, the effects of soil compaction were not observed below the $0-10 \mathrm{~cm}$ depth increment. There was also a reduction in POM-C and $\mathrm{N}$ in the disturbance zone but no measurable effect on $\mathrm{N}$ availability 
due to a high degree of variation in measurements associated with the soil incubations for determination of potential net soil $\mathrm{N}$ mineralization.

Overall, effects of the bulldozer on measures of soil quality were consistent with reported differences among sites subject to minimal, light, moderate, and heavy training regimes at Fort Benning, Georgia. Greater soil density, less soil C, and less C and N in surface POM has been reported at sites where soils have been repeatedly impacted by tracked-vehicle training (Garten et al., 2003). In the present study, differences between undisturbed and disturbed forest soils were detectable at one month after only a few passes with the D7 bulldozer. The null hypothesis for the experiment was, therefore, partially rejected because there were declines $(P \leq$ 0.10 ) in surface soil $\mathrm{C}$ and $\mathrm{N}$ as a consequence of heavy vehicle traffic. The removal of surface mineral soil by the bulldozer caused lower surface soil $\mathrm{C}$ and $\mathrm{N}$ concentrations in the disturbance zone. Although there was some tendency for greater soil $\mathrm{N}$ availability in disturbed soils, the changes were not significantly different from undisturbed controls. Thus, the null hypothesis with respect to soil $\mathrm{N}$ availability was not rejected. It is expected that repeated soil disturbance over time, which normally occurs in a military training area, would simply intensify the changes in soil properties that were measured following a one-time soil disturbance at the K-11 training compartment.

Finally, the experiment was also useful for identifying soil measurements that are particularly sensitive to disturbance and therefore can be used successfully as indicators of a change in soil properties as a result of heavy, tracked-vehicle traffic at Fort Benning. Measurements related to total O-horizon mass and $\mathrm{C}$ concentrations or stocks exhibited changes that ranged from $\approx 25$ to $75 \%$ following the one-time disturbance. Changes in surface $(0-10 \mathrm{~cm})$ mineral soil density or measures of surface soil $\mathrm{C}$ and $\mathrm{N}$ following the disturbance were less remarkable and ranged from $\approx 15$ to $45 \%$ (relative to undisturbed controls). Soil $\mathrm{N}$ availability (measured as initial extractable soil $\mathrm{N}$ or $\mathrm{N}$ production in laboratory incubations) was the least sensitive and the least useful indicator for detecting a change in soil quality as a result of heavy, tracked-vehicle disturbance. Collectively, the results suggest that the best indicators of a change in soil quality will be found at the soil surface because there were no statistically significant effects of bulldozer disturbance at soil depths below $10 \mathrm{~cm}$.

\section{REFERENCES}

Ayers, P.D. 1994. Environmental damage from tracked vehicle operation. Journal of Terramechanics 31: 173-183.

Belnap, J., and S.D. Warren. 2002. Patton's tracks in the Mojave Desert, USA: an ecological legacy. Arid Land Research and Management 16: 245-258.

Braunack M.V. 1986. The residual effects of tracked vehicles on soil surface properties. Journal of Terramechanics 23: 37-50. 
Cambardella, C.A., and E.T. Elliott. 1992. Particulate soil organic-matter changes across a grassland cultivation sequence. Soil Science Society America Journal 56: 777-783.

Garten, C.T., Jr., M.A. Huston, and C.A. Thoms. 1994. Topographic variation of soil nitrogen dynamics at Walker Branch Watershed, Tennessee. Forest Science 40: 497-512.

Garten, C.T., Jr., and T.L. Ashwood. 2004. Land Cover Differences in Soil Carbon and Nitrogen at Fort Benning, Georgia. ORNL/TM-2004/14. Oak Ridge National Laboratory, Oak Ridge, TN 37830.

Garten, C.T., Jr., T.L. Ashwood, and V.H. Dale. 2003. Effect of military training on indicators of soil quality at Fort Benning, Georgia. Ecological Indicators 3: 171-179.

Iverson R.M., B.S. Hinckley, R.M. Webb, and B. Hallet. 1981. Physical effects of vehicular disturbance on arid landscapes. Science 212: 915-917.

Johnson D.W., and P.S. Curtis. 2001. Effects of forest management on soil C and N storage: meta analysis. Forest Ecology and Management 140: 227-238.

Johnson, D.W., and P.S. Curtis. 2001. Effects of forest management on soil C and N storage: meta-analysis. Forest Ecology and Management 140: 227-238.

Prose, D.V. 1985. Persisting effects of armored military maneuvers on some soils of the Mojave Desert. Environmental Geology and Water Sciences 7: 163-170.

Prosser C.W., K.K. Sedivec, and W.T. Barker. 2000. Tracked vehicle effects on vegetation and soil characteristics. Journal of Range Management 53: 666-670.

Thurow T.L., S.D. Warren, and D.H. Carlson. 1993. Tracked vehicle traffic effects on the hydrologic characteristics of central texas rangeland. Transactions of the ASAE 36: 1645-1650.

Wan W., D. Hui, and Y. Luo. 2001. Fire effects on nitrogen pools and dynamics in terrestrial ecosystems: a meta-analysis. Ecological Applications 11: 1349-1365. 
ORNL/TM-2004/76

\section{INTERNAL DISTRIBUTION}

1-6. C.T. Garten, Jr., Bldg. 1505 (6038)

7. V.H. Dale, Bldg. 1505 (6036)

8. R.L. Graham, Bldg. 1505 (6036)

9. G.K. Jacobs, Bldg. 1505 (6035)

10. P.J. Mulholland, Bldg. 1505 (6036)
11-13. ESD Library

14. ORNL Central Research Library

15. ORNL Laboratory Records CRC

16. ORNL Laboratory Records BOSTI

\section{EXTERNAL DISTRIBUTION}

17. T.L. Ashwood, 418 Keota Lane, Loudon, TN 37774

18. H.E. Balbach, U.S. Army Engineer Research and Development Center (ERDC), P.O. Box 9005, Champaign, IL 61826-9005

19. W.D. Goran, U.S. Army Engineer Research and Development Center (ERDC), P.O. Box 9005, Champaign, IL 61826-9005

20. R. Washington-Allen, 14 Windhaven Lane, Oak Ridge, TN 37830

\section{ELECTRONIC NOTIFICATION}

21. Teresa Aden (Teresa.S.Aden@erdc.usace.army.mil)

22. Neil Burns (Burns.Neil@epamail.epa.gov)

23. John Brent (John.Brent@benning.army.mil)

24. Beverly Collins (collins@srel.edu)

25. Roger Dahlman (Roger.Dahlman@science.doe.gov)

26. John Dilustro (dilustro@srel.edu)

27. John Hall (john_hall@TNC.ORG)

28. Robert Holst (robert.holst@osd.mil)

29. Jennifer Jacobs (jjaco@ce.ufl.edu)

30. Louis Kaplan (lakaplan@stroudcenter.org)

31. Katherine Kirkman (kkirkman@jonesctr.org)

32. Rose Kress (kressr@wes.army.mil)

33. Tony Krzysik (krzysika@cableone.net)

34. Joe Prenger (jprenger@ufl.edu)

35. David Price (priced@wes.army.mil)

36. K. Ramesh Reddy (krr@mail.ifas.ufl.edu)

37. Pete Swiderek (swiderekp@benning.army.mil)

38. Hugh Westbury (Hugh.Westbury@Benning.Army.Mil) 